\title{
Sistem Manajemen Potensi Anak Sejak Dini (SIMPONI) Berdasarkan Teori Kecerdasan Majemuk Menggunakan Metode Simple Additive Weighting (SAW)
}

\author{
Mustafa ${ }^{*}$, Mustafid $^{2}$, R. Rizal Isnanto ${ }^{3}$ \\ ${ }^{1}$ Program Studi Teknik Informatika, Universitas Islam Sultan Agung Semarang \\ 2,3Program Studi Magister Sistem Informasi, Universitas Diponegoro Semarang \\ *cakmustafa@unissula.ac.id
}

\begin{abstract}
Abstrak
Program pembelajaran untuk anak Sekolah Dasar (SD) lebih mudah disampaikan apabila menggunakan strategi pembelajaran yang sesuai dengan gaya belajar atau profil kecerdasan majemuk anak. Identifikasi profil kecerdasan majemuk anak dapat dilakukan melalui proses observasi orang tua dan guru sekolah terhadap kegiatan sehari-hari anak. Profil kecerdasan majemuk anak bersifat dinamis sehingga perlu dilakukan identifikasi profil kecerdasan majemuk secara berkala minimal satu tahun sekali. Penelitian ini bertujuan untuk mengimplementasikan metode Simple Additive Weight (SAW) pada Sistem Manajemen Potensi Anak Sejak Dini (SIMPONI) berdasarkan Teori Kecerdasan Majemuk. Metode Simple Additive Weighting (SAW) digunakan untuk perhitungan penentuan rangking profil Kecerdasan Majemuk anak. Hasil penelitian ini adalah sistem informasi manajemen identifikasi Profil Kecerdasan Majemuk dengan pengolahan data menggunakan metode Simple Additive Weighting (SAW). Keunggulan produk yang dihasilkan penelitian ini adalah orang tua dapat melakukan identifikasi profil kecerdasan majemuk anak secara lebih mudah dibandingkan model sebelumnya yang menggunakan metode wawancara yang mengharuskan tatap muka.
\end{abstract}

Kata kunci: Gaya Belajar, Identifikasi, Kecerdasan Majemuk, Metode SAW, Potensi, Sistem Informasi Manajemen

\begin{abstract}
Learning program for elementary school age children will be more easily presented when using learning strategies according to the child's learning style or multiple intelligences profile. Identification of multiple intelligences profile child can be done through a process of observation of parents and teachers on children's daily activities. Children multiple intelligences profile is dynamic so it's necessary to identify multiple intelligence profiles on a regular basis for at least one year. This research aims to implement Simple Additive Weight (SAW) methode in Management Information Systems to Identification of Potential Early Childhood - SIMPONI based on the Theory of Multiple Intelligences. Simple Additive weighting methode (SAW) is used for calculation of the ranking of Multiple Intelligences profile child. The Results of this research is management information systems to identificaton Multiple Intelligences Profile with the data processing using Simple Additive weighting methode (SAW). The product advantages of this research is parents can identify multiple intelligence profile of children more easily than previous models that use a method that requires face-to-face interviews.
\end{abstract}

Keywords: Identification, Learning Style, Management Information Systems, Multiple Intelligences, Potential, SAW

\section{Pendahuluan}

Setiap orang tua pasti ingin memberikan program pendidikan yang terbaik untuk anak tercinta. Seharusnya program pendidikan yang tidak sekedar mengikuti keinginan orang tua namun sesuai dengan bakat atau potensi anak.
Teori Kecerdasan Majemuk mengambarkan kecerdasan dengan perspektif yang lebih luas sehingga kecerdasan tidak hanya dipandang dari konsep abstrak namun lebih pada fungsional yang dapat terlihat dalam perilaku sehari-hari dengan beragam cara yang lebih komprehensif 
mencakup delapan kecerdasan, yakni linguistik, logis-matematis, spasial, kinestetis, musikal, interpersonal, intrapersonal, naturalis [1].

Profil kecerdasan majemuk selain memberikan gambaran potensi kecerdasan anak juga dapat menginformasikan gaya belajar anak. Dengan gaya belajar yang sudah teridentifikasi tersebut maka orang tua ataupun guru dapat menyusun strategi pembelajaran terbaik untuk anak. Dengan strategi pembelajaran yang tepat maka anak akan dengan mudah menyerap materi pembelajaran yang disampaikan [1].

Oleh Karena itu dalam penelitian ini akan dirancang bangun Sistem Manajemen Potensi Anak Sejak Dini menggunakan metode SAW berdasarkan teori Kecerdasan Majemuk melalui proses observasi.

Tujuan penelitian ini adalah mengimplementasikan metode rangking Simple Additive Weight (SAW) untuk Sistem Manajemen Potensi Anak Sejak Dini (SIMPONI) berdasarkan Teori Kecerdasan Majemuk.

Dengan adanya penelitian ini diharapkan dapat memberikan manfaat sebagai berikut;

1. Mengoptimalkan fungsi observasi kegiatan harian untuk melakukan identifikasi profil kecerdasan majemuk anak/siswa.

2. Sistem Manajemen Potensi Anak Sejak Dini (SIMPONI) membantu orang tua dan guru untuk identifikasi potensi kecerdasan anak berdasarkan teori kecerdasan majemuk lebih cepat dan tepat. Hasil identifikasi profil kecerdasan anak melalui SIMPONI memberikan informasi kepada orang tua dan guru tentang strategi pembelajaran yang paling sesuai digunakan karena profil kecerdasan majemuk sekaligus sebagai gambaran gaya belajar anak/siswa.

\section{Tinjauan Pustaka}

\subsection{Penelitian Sebelumnya}

Teori kecerdasan majemuk dengan metode perhitungan AHP dapat digunakan dalam sistem pendukung keputusan untuk memberikan rekomendasi pilihan peminatan mahasiswa sebagai bahan pertimbangan. Dalam implementasinya didapatkan sebanyak $49 \%$ pemilihan peminatan sesuai antara rekomendasi berdasarkan sistem yang peminatan yang dipilih oleh mahasiswa [2].

Dalam pembelajaran, guru perlu memahami profil kecerdasan majemuk siswa sehingga dapat menerapkan strategi yang paling sesuai [3]. Profil kecerdasan majemuk siswa dapat menjadi pintu gerbang guru dalam penyampaian materi sehingga materi yang disampaikan dapat lebih mudah dipahami oleh siswa [4]. Identifikasi profil kecerdasan majemuk dapat menggunakan kuesioner menggunakan skala likert [5]. Identifikasi profil kecerdasan majemuk dapat dilakukan melalui sistem komputer berbasis web menggunkaan metode certainty factor. Profil kecerdasan majemuk yang dapat di identifiaksi tersebut dapat menjadi referensi potensi dan bakat siswa [6]. 


\subsection{Landasan Teori}

\section{Peran Teori Kecedasan Majemuk Dalam Pendidikan}

Pemahaman terhadap kecerdasan mulai mengalami perubahan tidak hanya dilihat dari $I Q$ sejak munculnya teori Multiple Inteligences (kecerdasan majemuk) dari seorang ahli Psikologi Kognitif Harvard University, Dr Howard Garnerd pada tahun 1983. Individu yang selama ini sering dikatakan kurang atau bahkan tidak cerdas hanya karena nilai pelajaran Matematika, Bahasa, Sains di bawah rata-rata meskipun mereka memiliki nilai rata-rata atau bahkan diatas rata-rata untuk mata pelajaran olahraga ataupun seni [1].

Melalui konsep kecerdasan majemuk (Multiple Intelligences), kecerdasan tidak sekedar dilihat dari kemampuan logika-matematika dan bahasa tetapi juga harus dilihat dari aspek lain diantarnya kinestetis, musical, visual-spasial, interpersonal, intrapersonal, dan naturalis.

Profil kecerdasan majemuk siswa dalam Pendidikan menjadi pintu gerbang bagi guru dalam Menyusun Rencan Pelaksanaan Pembelajaran (RPP). Penggunaan strategi pembelajaran yang disesuaikan dengan profil kecerdasan majemuk siswa akan membuat materi lebih mudah disampaikan kepada siswa. Profil kecerdasan majemuk siswa dapat diidentifikasi melalui proses observasi kegaitan harian siswa baik dirumah maupun disekolah [4]. Hal ini sesuai dengan pemahaman bahwa tidak ada satupun "test tercanggih" di masyarakat yang dapat menghasilkan survey yang komprehensif mengenai kecerdasan manjemuk siswa selain melalui Observasi [1].

Dalam penelitian identifikasi profil kecerdasan majemuk untuk siswa sekolah dasar, selain metode observasi dapat pula dilakukan melalui identifikasi portofoliso karya siswa dan wawancara dengan pihak yang sering berhubungan dengan siswa. Melalui proses analisa hasil identifikasi dari tiga metode tersebut maka profil kecerdasan majemuk siswa dapat teridentifikasi dengan baik [7]. Identifikasi profil kecerdasan majemuk melalui kegiatan obervasi dapat dilakukan dengan mengembangkan metode summated rating dari Likert [8].

\section{Simple Additive Weight (SAW)}

Simple Additive Weighting (SAW) merupakan metode penentuan rangking melalui perhitungan metode penjumlahan terbobot dari beberapa alternative pilihan. Perhitungan menggunakan metode SAW dapat menghasilkan nilai terbesar yang akan dipilih sebagai alternatif yang terbaik. Metode ini banyak digunakan untuk berbagai sistem pendukung keputusan karena metode ini konsepnya simpel, mudah digunakan dan dipahami [9].

Tujuan utama dalam perhitunggan menggunakan metode SAW pada dasarnya untuk mengevaluiasi m alternatif $A i(i=1,2, \ldots . m)$ terhadap sekumpulan atribut atau kriteria $C j(j=1,2, \ldots \ldots, n)$, dimana setiap atribut saling tidak bergantung satu dengan yang lainnya. Matriks keputusan setiap alternatif 
terhadap setiap atribut $X$ diberikan sebagai berikut: [10]

$X=\left[\begin{array}{cccc}X_{11} & X_{12} & \cdots & X_{1 n} \\ X_{21} & X_{22} & \cdots & X_{2 n} \\ \vdots & \vdots & \cdots & \vdots \\ X_{m 1} & X_{m 2} & \cdots & X_{m n}\end{array}\right]$

Dimana $X_{i j}$ merupakan rating kinerja alternatif ke-i terhadap atribut ke-j. Nilai bobot yang menunjukkan tingkat kepentingan relatif setiap atribut, diberikan sebagai, W:

$W=\left\{w_{1}, w_{2}, \ldots \ldots ., w_{n}\right\}$

Dalam perhitungan untuk menghasilkan rangking menggunakan metode SAW dikenal adanya 2 atribut yaitu kriteria keuntungan (benefit) dan kriteria biaya (Cost) serta membutuhkan proses normalisasi matriks keputusan $(X)$ ke suatu skala yang dapat diperbandingkan dengan semua rating alternatif yang ada. Formula untuk melakukan proses normalisasi berdasarkan kriteria keuntungan ataupun kriteria biaya dapat dilihat pada rumus berikut [11]:

$r_{i j}=\left\{\begin{array}{l|l}\frac{x_{i j}}{M a x x_{i j}} & \text { Jikaj adalah atribut keberuntungan (benefit) } \\ \hline \frac{\text { Min } x_{i j}}{X_{i j}} & \text { Jikaj adalah atribut biaya (cost) } \\ & \end{array}\right.$

Dimana $r_{i j}$ adalah rating kinerja ternormalisasi dari alternatif $A i$ pada atribut $C_{j} ; \mathrm{i}=1,2, \ldots, \mathrm{m}$ dan $j=1,2, \ldots, n$.

Selanjutnya untuk menentukan pilihan alternatif terbaik dapat dilihat dari perhitungan nilai preferensi. Nilai prefesensi untuk setiap alternatif (Vi) untuk menentukan alternatif mana yang akan menjadi yang terbaik. Dalam hal ini nilai $V i$ yang lebih besar mengindikasikan bahwa alternatif $A i$ lebih terpilih. Rumus untuk mendapatkan nilai Vi dapat dilihat pada rumus berikut:

$$
V_{i}=\sum_{j=1}^{n} w_{j} R_{i j}
$$

Keterangan :

$V_{i}=$ Nilai untuk rangking setiap alternatif $\mathrm{w}_{\mathrm{j}} \quad=$ Nilai bobot dari setiap kriteria $r_{i j}=$ Nilai rating kinerja ternormalisasi

\section{Metode Penelitian}

Tahapan penelitian pengembangan Sistem Manajemen Potensi Anak Sejak Dini (SIMPONI) Berdasarkan Teori Kecerdasan Majemuk Menggunakan Metode Simple Additive Weighting (SAW) meliputi tahapan-tahapan sebagai berikut

\subsection{Tahap Perencanaan Penelitian}

Pada tahapan ini akan dilakukan perencanaan untuk melakukan penelitian meliputi tahapan untuk studi pustaka, desain kuesioner, pengembangan SIMPONI.

\subsection{Tahap Penyusunan kuesioner dan Pembobotan observer}

Dalam proses penyusunan kuesioner ini akan dilakukan diskusi mendalam dengan psikolog. Pembobotan pada tiap kategori observer yang melakukan input kuesioner terdiri dari;

Tabel 1. Pembobotan dalam perhitungan metode SAW sesuai dengan hubungan observer dengan siswa yang diobservasi

\begin{tabular}{|lcc|}
\hline \multicolumn{1}{|c}{ Bobot } & \multicolumn{1}{c}{ Keterangan } & $\begin{array}{c}\text { Nilai } \\
\text { Bobot }\end{array}$ \\
\hline Sangat & $\begin{array}{l}\text { Keluarga inti meliputi } \\
\text { orang tua, kakek/nenek, } \\
\text { Tinggi } \\
\text { kakak/adik yang tinggal } \\
\text { satu rumah }\end{array}$ & \\
& & \\
\hline
\end{tabular}




\begin{tabular}{|lll|}
\hline Tinggi & - Keluarga support yang & 3 \\
& konsisten memiliki & \\
& interaksi dengan anak \\
& namun tidak tinggal \\
& serumah. \\
& - Guru di sekolah yang \\
& memiliki interaksi \\
& konsisten setiap hari \\
& dengan anak \\
\hline Cukup & - Guru di sekolah yang \\
& memiliki interaksi \\
& setidaknya sehari \\
& dalam 1 minggu \\
& - Guru kursus/les yang \\
& memiliki interaksi \\
& setidaknya sehari \\
& dalam 1 minggu \\
\hline
\end{tabular}

\subsection{Tahap Perancangan sistem}

Pada tahap ini melakukan penyusunan Use Case Diagram dan diagram aktivitas untuk input dan keluaran. Selanjutnya akan dilakukan pembuatan kode program sesuai dengan perancangan sistem.

\subsection{Tahap Implementasi}

Tahap implementasi adalah tahapan untuk pembuatan aplikasi sesuai dengan perancangan sistem yang telah disusun. Pada tahapan ini dilakukan juga ujicoba sistem secara bertahap sehingga jika ada kesalahan dapat diperbaiki sejak awal.

\subsection{Tahap Pengujian Sistem}

Tahap pengujian sistem meliputi proses kegiatan verifikasi dan validasi. Untuk kegiatan verifikasi akan dilakukan pengujian menggunakan data dummy yang selanjutnya dilakukan perbandingan dengan requirement sistem yang telah ditentukan.
Pada tahap ujicoba validasi peneliti melakukan pengambilan data input kuesioner observasi kegiatan anak secara manual kepada orang tua siswa, guru harian dan guru pendamping di sekolah.

\section{Hasil dan Pembahasan}

a. Proses Aplikasi SIMPONI

Proses aplikasi Sistem Manajemen Potensi Anak Sejak Dini (SIMPONI) dari input-proses dan keluaran dapat dilihat pada Gambar 1.;

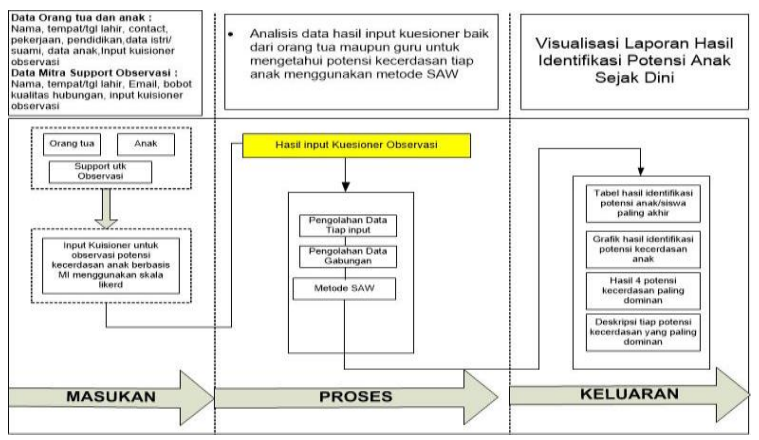

Gambar 1 Proses aplikasi SIMPONI dari InputProses-Keluaran

b. Perancangan Sistem

1) Diagram Use Case

Diagram use case secara keseluruhan dapat dilihat pada Gambar 2.

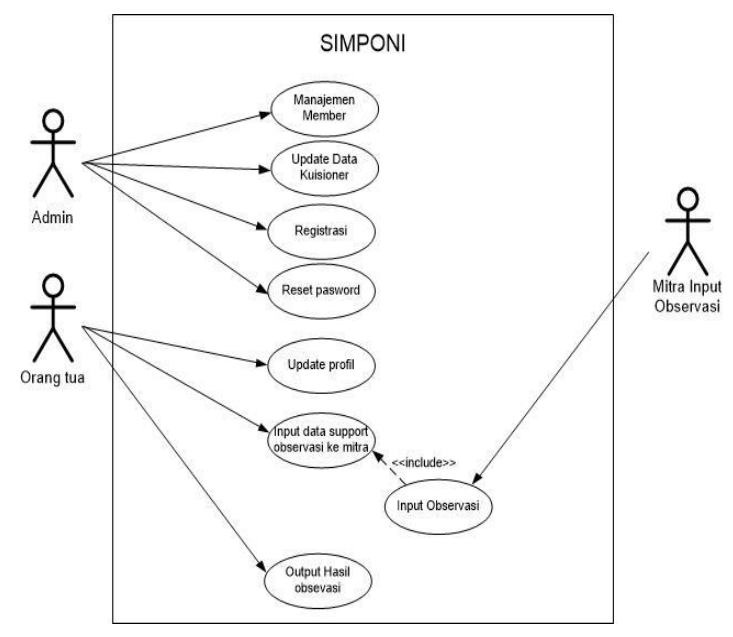

Gambar 2 Diagaram Use Case SIMPONI 
2) Diagram Aktivitas akun orang tua

Proses aktivitas yang dapat dilakukan oleh orang tua dapat dilihat pada gambar 3.3 berikut ini:

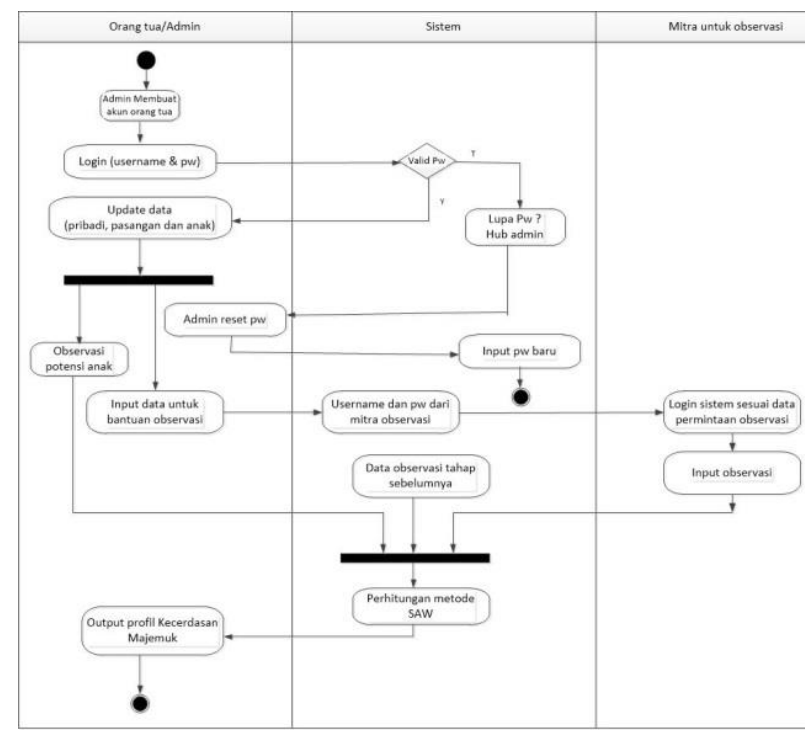

Gambar 3 : Diagram aktivitas akun orang tua

\section{c. Pembahasan}

Hasil penelitian ini adalah Sistem Manajemen Potensi Anak Sejak Dini (SIMPONI) dengan menerapkan metode SAW untuk menentukan rangking yang paling dominan dari 8 (delapan) jenis potensi kecerdasan anak berdasarkan teori kecerdasan majemuk. Masukan untuk aplikasi SIMPONI didapatkan melalui pengisian kuesioner observasi kegiatan harian anak. Masukan data observasi kegiatan harian anak disediakan dalam aplikasi SIMPONI dalam bentuk list pernyataan yang selanjutnya observer melakukan checklist berdasarkan kesesuaian antara pernyataan dengan kegiatan harian anak. Untuk mengoptimalkan hasil identifikasi potensi kecerdasan anak, SIMPONI menyediakan formulir pengisian kuesioner dari observer selain dari orang tua dengan pembobotan sesuai kualitas interaksi observer dengan kegiatan harian anak.

Proses pengolahan data dari masukan kuesioner hasil observasi menggunakan metode SAW untuk mendapatkan hasil rangking potensi kecerdasan anak. Selanjutnya hasil rangking potensi kecerdasan tersebut ditampilkan pada luaran SIMPONI dalam bentuk grafik dan khusus 4 (empat) nilai tertinggi hasil identifikasi potensi kecerdasan tersebut akan dideskripsikan sebagai profil kecerdasan majemuk.

Hasil identifikasi potensi kecerdasan anak berdasarkan teori kecerdasan majemuk sekaligus dapat memberikan informasi gaya belajar paling tepat yang dimiliki oleh anak sehingga berdasarkan hasil identifikasi ini para orang tua dan guru dapat menyusun strategi pembelajarn atau program pendidikan yang paling tepat kepada anak/siswa.

Berdasarkan hasil diskusi dengan konsultan pendidikan kecerdasan majemuk, didapatkan bahwa potensi kecerdasan atau gaya belajar anak tidak bisa dilakukan dengan satu kali proses karena pada dasarnya potensi kecerdasan atau gaya belajar anak sangat dipengaruhi oleh lingkungan sekitar. Proses identifikasi bertahap ini dapat dilakukan dengan rentang waktu paling tidak 3 bulan sehingga hasilnya akan lebih valid. Hasil identifikasi tahap sebelumnya juga menjadi referensi perhitungan menentukan potensi kecerdasan anak. Oleh karena itu pengembangan sistem informasi dalam penelitian ini akan memberi manfaat yang besar untuk kecepatan dan ketepatan dalam 
melakukan perhitungan hasil observasi kegiatan keseharian anak.

1) Sistem Manajemen Potensi Anak Sejak Dini (SIMPONI)

Penelitian ini menghasilkan aplikasi Sistem Manajemen Potensi Anak Sejak Dini (SIMPONI) yang memiliki fungsi utama yaitu untuk menentukan rangking potensi anak melalui proses observasi berdasarkan teori Kecerdasan majemuk menggunakan metode perhitungan Simple Additive Weighting (SAW) atau disebut sebagai profil kecerdasan majemuk.

Pengembangan aplikasi SIMPONI dapat optimalkan oleh orang tua maupun sekolah. Tampilan utama aplikasi SIMPONI ditunjukan pada Gambar 4.1. Proses pendaftaran untuk mendapatkan akun dilakukan melalui admin sistem.

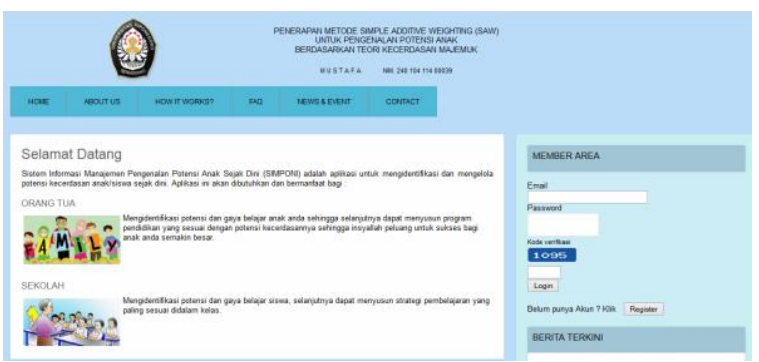

Gambar 4 Tampilan utama aplikasi SIMPONI

Berikut penjelasan penggunaan aplikasi SIMPONI oleh orang tua:

\section{a) Pendaftaran aplikasi SIMPONI}

Pendaftaran akun pengguna orang tua oleh admin dapat dilakukan melalui menu kelola user dengan tampilan aplikasi seperti pada Gambar 5 Selain pengelolaan user, admin dapat melakukan update kuesioner pada menu master data dengan pilihan data survey.

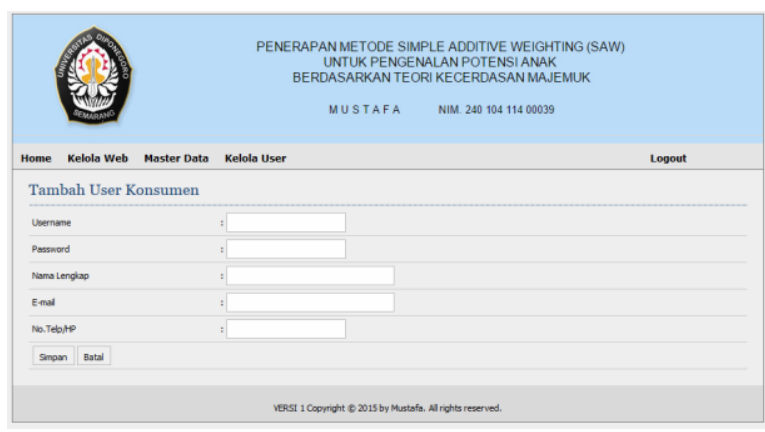

Gambar 5. Formulir pendaftaran untuk menggunakan aplikasi SIMPONI

Setelah melakukan pendaftaran maka sistem akan mengirimkan email pemberitahuan untuk melakukan aktivasi. Setelah melakukan aktivasi maka user dapat menggunakan aplikasi SIMPONI.

\section{d. Pengujian Sistem}

Pembahasan hasil penelitian ini akan dibagi menjadi dua yaitu pengujian sistem SIMPONI mulai dari proses input data dalam sistem hingga tampilan keluaran dan pengujian validitas analisa data perhitungan menggunakan metode Simple Addtive Weighting (SAW). Dalam pengujian ini peneliti menggunakan metode back box yaitu pengujian yang berfokus pada fungsional aplikasi SIMPONI berdasarkan perancangan desain yang sudah disusun. Selain itu, dalam pengujian akan dilakukan pula validitas pengeolahan data dengan membandingkan hasil keluaran pengolahan melalui sistem dengan hasil pengolahan data secara manual.

Berdasarkan metode pengujian sistem blackbox test didapatkan hasil pengujian untuk akun orang tua sebagai berikut: 
Tabel 2. Hasil pengujian SIMPONI menggunakan metode Blackbox Test

\begin{tabular}{|c|c|c|c|}
\hline No & Butir Pengujian & $\begin{array}{l}\text { Hasil yang } \\
\text { diharapkan }\end{array}$ & Hasil \\
\hline 1 & $\begin{array}{l}\text { Member area dan } \\
\text { pendaftaran }\end{array}$ & $\begin{array}{l}\text { Tampil kepada } \\
\text { halaman formulir } \\
\text { pendaftaran }\end{array}$ & Sesuai \\
\hline 2 & $\begin{array}{l}\text { Pengelolaan data } \\
\text { pengguna }\end{array}$ & $\begin{array}{l}\text { Akun orang tua } \\
\text { berhasil dibuat }\end{array}$ & Sesuai \\
\hline 3 & $\begin{array}{l}\text { Pengelolaan } \\
\text { kuesioner }\end{array}$ & $\begin{array}{l}\text { Tampil halaman } \\
\text { pengelolaan data } \\
\text { kuesioner }\end{array}$ & Sesuai \\
\hline 4 & Login pengguna & $\begin{array}{l}\text { User dapat login } \\
\text { dan halaman } \\
\text { dashboard } \\
\text { aplikasi SIMPONI }\end{array}$ & Sesuai \\
\hline 5 & $\begin{array}{l}\text { Update profil orang } \\
\text { tua }\end{array}$ & $\begin{array}{l}\text { Halaman profil } \\
\text { orang tua } \\
\text { terupdate }\end{array}$ & Sesuai \\
\hline 6 & Update profil anak & $\begin{array}{l}\text { Data anak bisa } \\
\text { update }\end{array}$ & Sesuai \\
\hline 7 & $\begin{array}{l}\text { Permintaan } \\
\text { dukungan observasi }\end{array}$ & $\begin{array}{l}\text { Data dukungan } \\
\text { untuk observasi } \\
\text { terupdate dan } \\
\text { dapat melakukan } \\
\text { input data } \\
\text { kuesioner } \\
\text { observasi. }\end{array}$ & Sesuai \\
\hline 8 & Keluaran observasi & $\begin{array}{l}\text { Tampilan } \\
\text { halaman pilihan } \\
\text { untuk melihat } \\
\text { hasil dukungan } \\
\text { observasi untuk } \\
\text { setiap anak yang } \\
\text { sudah di input } \\
\text { oleh orang tua }\end{array}$ & Sesuai \\
\hline
\end{tabular}

1) Pengujian Validitas Pengolahan Data akun orang tua

Pada akun orang tua kami melakukan pengujian validitas pengolahan data melalui dua kondisi yaitu pengolahan data jika orang tua tidak melakukan permintaan dukungan observasi kepada pihak manapun dan pengujian pengolahan data ketika orang tua melakukan permintaan dukungan observasi kepada pihak lain.

2) Pengujian Validitas Pengolahan Data tanpa dukungan observasi

Pada kondsi pertama yaitu orang tua tidak melakukan permintaan dukungan observasi kepada pihak lain. Data yang digunakan berdasarkan hasil observasi dari orang tua untuk Ahmad Naufal Aziz. Berdasarkan input hasil observasi tersebut, output dari SIMPONI ditunjukan pada Gambar 6.

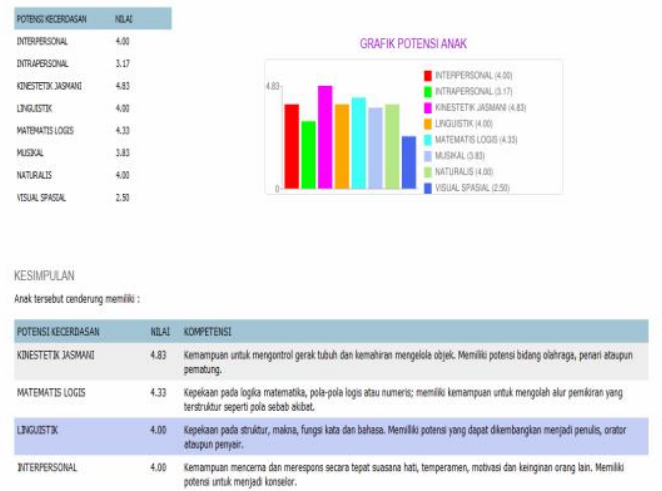

\section{Gambar 6 Keluaran SIMPONI dari observasi} orang tua

3) Pengujian Validitas Pengolahan data dengan dukungan observasi bobot hubungan tinggi dan cukup

Selanjutnya pada kondisi kedua yaitu orang tua melakukan permintaan dukungan observasi kepada pihak lain.sehingga SIMPONI menampilkan output yang ditunjukan pada Gambar 7.

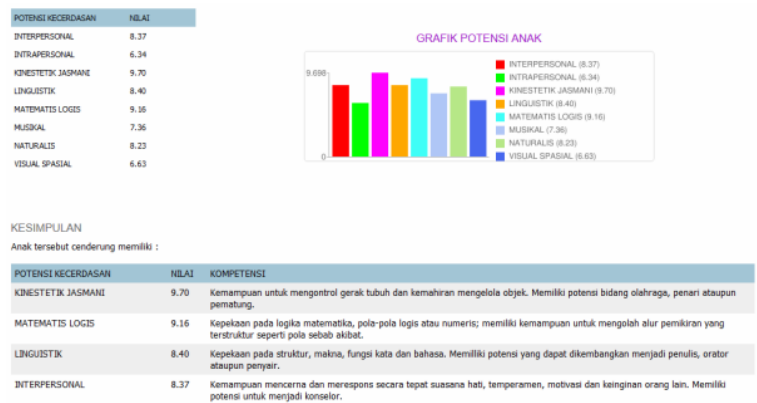

Gambar 7. Keluaran SIMPONI observasi orang tua dan dukungan observasi hubungan tinggi dan cukup 


\section{Kesimpulan}

Metode Simple Additive Weighting (SAW) dapat diterapkan untuk menentukan rangking potensi kecerdasan anak yang didapatkan dari hasil input data pernyataan kuesioner berdasarkan observasi kegiatan harian anak untuk menghasilkan profil kecerdasan majemuk.

Penelitian ini menggunakan alternatif yang dijadikan dasar pengambilan keputusan diantaranya: Linguistik, Matematis logis, Visual Spasial, Kinestetik, Musikal, Interpersonal, Intrapersonal, Naturalis. Selanjutnya kriteria yang dijadikan parameter dalam perhitungan metode SAW berdasarkan kualitas hubungan antara observer dengan anak yang akan di observasi. Kualitas hubungan ini terdiri dari tiga kriteris yaitu sangat tinggi, tinggi dan cukup.

Nilai alternatif $\mathrm{Ai}$ pada setiap kriteria $\mathrm{Cj}$ didapatkan dari hasil input data observasi kegiatan keseharian anak dengan menggunakan skala pengukuran tipe skala Likert. Nilai bobot (W) untuk tiap kriteria adalah 5 untuk kualitas hubungan sangat tinggi, 3 untuk kualitas hubungan tinggi dan 2 untuk kualitas hubungan cukup.

Aplikasi SIMPONI memudahkan orang tua dan guru untuk manajemen profil potensi Kecerdasan Majemuk anak/siswa karena semua tersimpan dalam basis data yang dapat diakses setiap saat. Hasil pengolahan data dengan metode SAW baik secara manual menggunakan excel dan pengolahan data melalui sistem menghasilkan keluaran yang sama

\section{Daftar Pustaka}

[1] T. Amstrong, Sekolah Para Juara. Kaifa Bandung, 2002.

[2] F. Purnomo, B. Sarikho, A. Sutanto, R. Peminatan, and A. Database, "Analisis Dan Perancangan Decision Support System Untuk Rekomendasi Peminatan Berdasarkan 9 Kecerdasan Manusia Dengan Metode Constrained Fuzzy Ahp," vol. 2010, no. Snati, pp. 7-12, 2010.

[3] I. M. González-Treviño, G. M. NúñezRocha, J. M. Valencia-Hernández, and A. Arrona-Palacios, "Assessment of multiple intelligences in elementary school students in Mexico: An exploratory study," Heliyon, vol. 6, no. 4, p. e03777, 2020, doi: https://doi.org/10.1016/j.heliyon.2020.e0377 7.

[4] M. Qomarudin, M. Mustafa, and M. A. Basir, "Pengembangan Model Pembelajaran Adaptive Berdasarkan Teori Kecerdasan Majemuk," JSHP ( J. Sos. Hum. dan Pendidikan), vol. 2, no. 1, p. 69, 2018, doi: 10.32487/jshp.v2i1.294.

[5] Farida Agus Setiawati, "Penskalaan Tipe Likert Dan Thurstone Dengan Teori Klasik Dan Modern : Studi Pada Instrumen Multiple Intelligences," 2013.

[6] S. A. Seputro and F. Masya, "Assessment of Student'S Interests and Talents Using the Web-Based Certainty Factor Method," J. Ris. Inform., vol. 2, no. 3, pp. 131-136, 2020, doi: 10.34288/jri.v2i3.139.

[7] E. Ladyawati and O. T. S. Dewi, "Identifikasi 
Kecerdasan Majemuk (Multiple Intellegences) pada Siswa Sekolah Dasar," Wahana, vol. 62, no. 1. pp. 15-23, 2014.

[8] F. A. Setiawati, "Penskalaan multiple intelligences sebagai salah satu alternatif instrumen untuk mengukur karakter bangsa yang cerdas," Konf. HEPI di Unesa., 2012.

[9] S. Rinaldi, T. Informatika, and K. Dosen, "Implementasi Metode Analytical Hierarchy Proces S Dan Simple Additive Weighting Untuk Pemilihan Dosen Terbaik Studi Kasus Decision Support System To Choose the Best Lecturer Performance With Analytical Hierarchy Proces S and Simple," J. Teknol. Inf. dan IImu Komput., vol. 6, no. 6, pp. 655-
664, 2019, doi: 10.25126/jtiik.201961636.

[10] V. C. Hardita, E. Utami, and E. T. Luthfi, "Penerapan Simple Additive Weighting pada Pemilihan Canvasser Terbaik PT.Eratel Prima," J. Teknol. Inf. dan IImu Komput., vol. 6, no. 5, p. 567, 2019, doi: 10.25126/jtiik.2019651218.

[11] J. Hutahaean and M. Badaruddin, "Sistem Pendukung Keputusan Pemilihan Sekolah SMK Swasta Penerima Dana Bantuan Menerapkan Metode Simple Additive Weighting ( SAW )," vol. 4, no. April, pp. 466-471, 2020, doi: 10.30865/mib.v4i2.2109. 